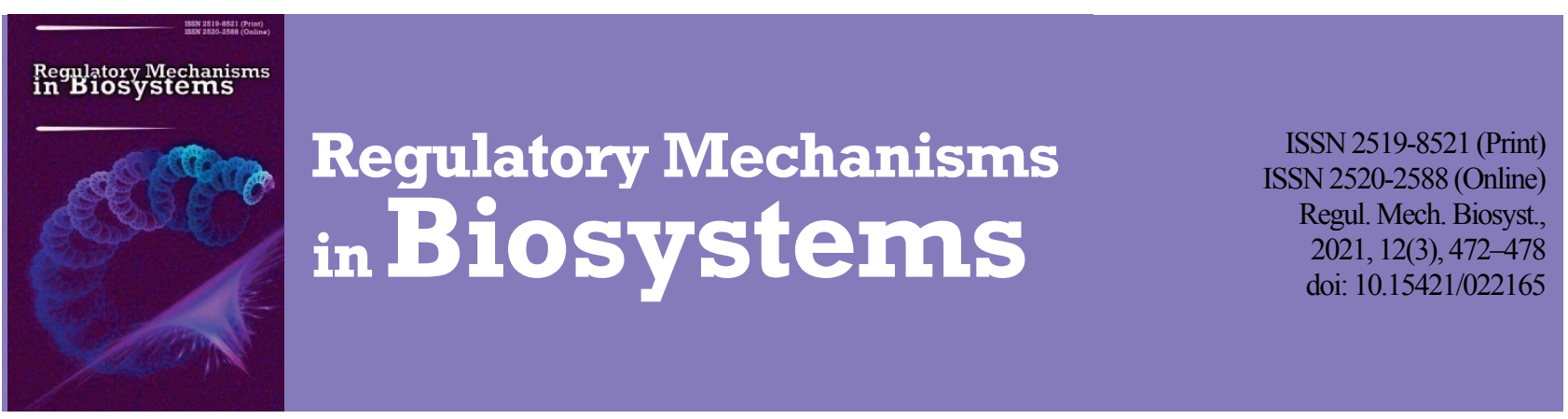

\title{
Efficacy of acriflavin chloride and Melaleuca alternifolia extract against Saprolegnia parasitica infection in Pterophyllum scalare
}

\author{
I. V. Lavrinenko, L. V. Shulha, O. O. Peredera, I. A. Zhernosik, R. V. Peredera \\ Poltava State Agrarian University, Poltava, Ukraine
}

Article info

Received 21.06.2021

Received in revised form 17.07.2021

Accepted 18.07.2021

Poltava State Agrarian University, Skovoroda st., 1/3, Poltava, 36003, Ukraine Tel.: +38-099-163-37-13. E-mail:ua151@ukr.net

\begin{abstract}
Lavrinenko, I. V., Shulha, L. V., Peredera, O. O., Zhernosik, I. A., \& Peredera, R. V. (2021). Efficacy of acriflavin chloride and Melaleuca alternifolia extract against Saprolegnia parasitica infection in Pterophyllum scalare. Regulatory Mechanisms in Biosystems, 12(3), 472-478. doi:10.15421/022165

The article describes cases of saprolegniosis in Pterophyllum scalare in private aquaristics and assesses the therapeutic efficacy of acriflafin chloride against Saprolegnia parasitica infection. To establish the diagnosis, the clinical signs present in sick fish, the results of mycological and microscopic examinations are taken into account. Some chemical and mycological indices of aquarium water have been studied, and also mycological studies of fish feed have been carried out. It is established that the disease of fish develops against the background of adverse changes in physical, chemical composition and microbiocenosis of aquarium water. Low water temperature, high levels of phosphates and $\mathrm{pH}$, a significant level of organic pollution, compared to the norm, provoke the accumulation of opportunistic microbiota, resulting in imbalance in the parasite-host system and the development of clinical manifestations of saprolegniosis in fish. It was found that $44.4 \%$ of the studied feed samples fed to fish were contaminated with epiphytic micromycetes. Micromycetes are represented by the genera Aspergillus, Penicilium, Fusarium, Mucor, Rhizopus. Among the studied feeds, the most affected by fungi were larvae of Chironomus plumosus and dry Daphnia pulex. According to the results of our studies during outbreaks of saprolegniosis, the $\mathrm{pH}$ of aquarium water was $8.1 \pm 0.7$, the content of phosphates $-5.6 \pm 1.1 \mathrm{mg} / \mathrm{L}$, micromycetes $-18.0 \pm 1.2 \mathrm{CFU} / 100 \mathrm{~cm}^{3}$. Aspergillus flavus, A. niger and Penicillium canescens were detected in the studied water samples. With saprolegniosis, the angelfish have a reduced appetite, spots, ulcers, white thin threads, and a cotton-like plaque appear on certain areas of the skin, fins, eyes, and gills. It is established that effective means for the treatment of sick fish are external use in the form of a long bath of acriflavine chloride and extract of $\mathrm{Melaleu}$ ca alternifolia. It is also effective to increase the water temperature to $25-27^{\circ} \mathrm{C}$, to ensure the normative fish-holding density in aquariums and to exclude from the diet fish feed contaminated with micromycetes. After using the drugs for two weeks every other day, water was replaced by $20 \%$ of the aquarium volume and aerated. As a result of the treatment, gradual healing of skin lesions and recovery of $65 \%$ of fish with signs of lesions of the outer coverings were registered. Thus, the article analyzes the causes of saprolegniosis in angelfish common in private aquariums, describes the clinical signs of the disease and assesses the therapeutic efficacy of acriflavine chloride and $M e l a-$ leuca alternifolia extract against Saprolegnia parasitica infection. Prospects for further research lie in search of more effective and environmentally friendly means for the treatment of saprolegniosis in aquarium fish.
\end{abstract}

Keywords: Saprolegniales; mycoses; micromycetes; acriflavine chloride; Melaleuca alternifolia extract; fish.

\section{Introduction}

In the modern world, aquarium fish farming is actively developing and gaining more and more popularity. Each aquarium is a unique ecosystem, in which the biological imbalance causes corresponding consequences. The most important factors that disrupt the qualitative and quantitative composition of the water microbiota are pathogens of infectious and invasive diseases (Gallani et al., 2016; Lange et al., 2020).

Diseases affecting aquarium fish are a global problem and need to be comprehensively studied (Carrias et al., 2012). Oomycetes are a diverse group of filamentous eukaryotic microbiota that includes animal and plant pathogens (Gaulin et al., 2010). Many representatives of Saprolegniales (Oomycetes) cause fungal diseases of fish, among which the most common genera are Achlya and Saprolegnia (Kar, 2016; Wuensch et al., 2018; Choi et al., 2019). Oomycetes are divided into three subclasses: Saprolegniomycetidae, Rhipidiomycetidae and Peronosporomycetidae, each of them can infect a wide range of hosts. Pathogenic oomycetes of fish belonging to the series Saprolegniales of the subclass Saprolegniomycetidae include three main genera: Saprolegnia, Achlya and Aphanomyces (Van West et al., 2010). An important role is also played by Saprolegniales of the genera Aphanomyces, Calyptralegnia, Dictyuchus, Leptolegnia, Pythiopis and Thraustotheca, Pythium (Watkinson et al., 2016).
Species of the genus Saprolegnia are classified by morphological characteristics, molecular studies have established their significant diversity. The most common species are S. diclina, S. ferax, S. australis and S. parasitica (Ke et al., 2009). A study performed in Korea from fish identified seven isolates of saprolegniosis pathogens, morphological and molecular phylogenetic analysis of which permitted them to be identified as Achlya americana and $A$. bisexualis (Choi et al., 2019). Oomycetes isolated from cichlids in South Africa have been identified as A. bisexualis (GreeffLaubscher et al., 2019).

Molecular studies and phylogenetic analysis of the DNA region of isolates are used to identify pathogens. Mycological studies involve incubation of isolates on potato agar dextrose (PDA) at different temperatures, from 5 to $25^{\circ} \mathrm{C}$ to monitor growth rates (Greeff-Laubscher et al., 2019).

Saprolegniosis is characterized by damage to the epidermis of fish. The lesion begins on the fins or head and often spreads over the entire body, manifesting as white or grey spots. Spores enter the body of fish, usually through damaged gills. Saprolegnia can also infect fish eggs. Ulcerative mycosis and epizootic ulcerative syndrome, which can cause mass mortality among fish, are mainly caused by Aphanomyces invadans. Significant skin lesions that look like red spots, black or red sores with white fringes, contain hyphae that can penetrate deep into the fish outside the muscles, damaging the brain, vertebrae and other organs (Watkinson 
et al., 2016). There is a clear seasonal dynamic in the spread of Saprolegniales with a slight decrease in the incidence of the disease in summer, which is associated with an increase in water temperature. Pathogens do not have a broad substrate specificity of fungi, but show specific activity against substrates based on cellulose or chitin (Masigol et al., 2020).

There are promising studies aimed at finding cost-effective and sustainable therapeutic agents for the treatment of fish saprolegniosis. It is also important to elucidate the interaction between the pathogen and the host during the use of drugs and the influence of environmental factors on these interactions (Carrias et al., 2012). Understanding the environmental factors that contribute to the evolution of pathogens on a modern scale is a necessary factor in controlling disease outbreaks among fish (Pulkkinen et al., 2018; Sundberg \& Karvonen, 2018). It is important to develop effective measures to combat and prevent infectious diseases of fish.

The purpose of our work is to analyze the causes of saprolegniosis in angelfish common in private aquariums, to describe the clinical signs of the disease and to establish the therapeutic efficacy of acriflavine chloride and Melaleuca alternifolia extract against Saprolegnia parasitica infection.

\section{Materials and methods}

The study was performed in accordance with the requirements of the European Convention for the Protection of Vertebrate Animals used for Research and other Scientific Purposes (Strasbourg, 1986) and the Law of Ukraine on the Protection of Animals from Cruelty (2006). The study program is coordinated with the Commission on Bioethics of Poltava State Agrarian University. Clinical and experimental studies were performed on the basis of the Department of Infectious Diseases, Hygiene, Sanitation and Biosafety. Observation objects were eight aquariums with the volume of 100 to 450 liters, with different species of fish: Pterophyllum scalare, Puntius tetrazona, Balantiocheilos melanopterus, Trichogaster leeri, Trichogaster chuna. The approximate number of fish in aquariums for 250-450 liters ranged from 70 to 90 adults, in aquariums for 100-150 liters from 20 to 60 . Water temperature was within the range from 20 to $27^{\circ} \mathrm{C}$, lighting was provided by fluorescent lamps, external filters were used for water purification. Fish were fed once a day - in the morning, given dry, frozen (Daphnia pulex, Artemia salina), as well as live food (larvae of Chironomus plumosus). Diagnosis was carried out comprehensively: taking into account clinical signs and the results of mycological and microscopic examinations. Clinical studies were performed according to conventional methods, which included a detailed history. Mycological studies included selection, microscopy and inoculation of material on nutrient media, isolation and identification of the pathogen, study of morphological, cultural and biological properties. We took into account: the size of the colonies, their structure, colour and nature of growth. During microscopic examination of cultures, the structure, thickness of the mycelium, shape and size of microconidia were noted. Identification of fungi was performed on an atlas for identification of micromycetes (Sutton, 2001).

Chemical parameters of water were determined using test systems (Ptero, Ukraine, 2020), in particular: the content of nitrates, phosphates and $\mathrm{pH}$. Mycological studies of aquarium water samples were also performed: the total number of micromycetes was determined. Determination of microscopic fungi in water was based on sowing water samples on a specific agar nutrient medium, followed by incubation, counting and identification of colonies grown on agar. The technique includes preparation of water samples, filtration through membrane filters, which were then applied to the surface of Saburo medium with dichlorane followed by incubation. The number of grown colonies of micromycetes was counted, taking into account the multiplicity of sample dilutions. The result was expressed in colony-forming units (CFU) in $100 \mathrm{~cm}^{3}$ of the test water sample.

Mycological studies and determination of feed toxicity were performed in accordance with the guidelines for sanitary-mycological assessment and improvement of feed quality (Obrazhej et al., 1998). To identify fungi, microscopic examinations of preparations from mycelial particles with sporulation by the crushed drop method were performed. Identification of fungi was performed using an atlas for identification of micromycetes (Sutton, 2001). Mycological studies of different types of feed used for feeding aquarium fish were carried out. In particular, fresh feed sam- ples: larvae of $C$. plumosus and frozen $A$. salina. Dry feeds fed to aquarium fish were also studied: samples of dried $D$. pulex, granular feeds: dry feed for aquarium fish in "TetraPro Energy" chips (Tetra, Germany) and dry feed in "TetraMin" flakes (for all aquarium species) (Tetra, Germany) (Fig. 1).
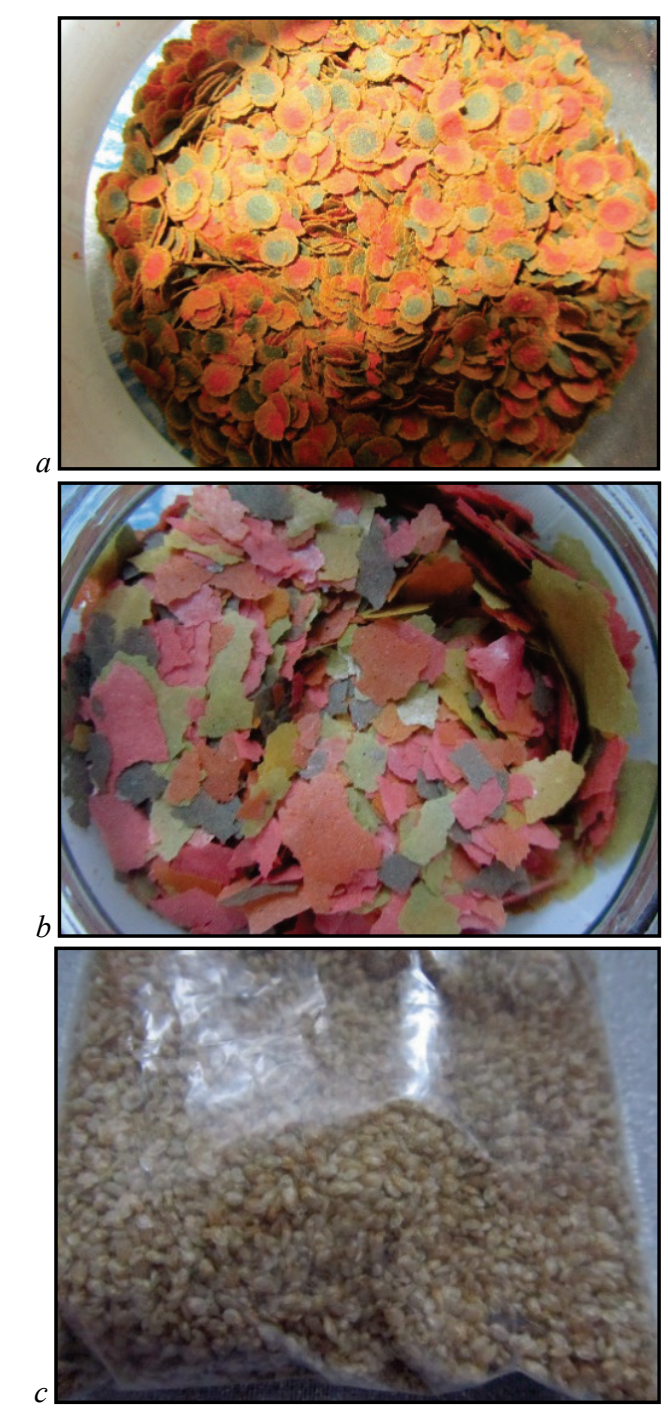

Fig. 1. Samples of dry fish feed: $a$ - "TetraPro Energy" (Tetra, Germany), $b$ - "TetraMin" (Tetra, Germany), $c$-Daphnia pulex (dried)

Based on the studies performed, a set of measures to eliminate and prevent the disease was developed. "Tetra Medica FungiStop Plus" (Tetra, Germany) was used to treat fungal and bacterial infections. The content of active substances in $1 \mathrm{ml}$ of solution: $4.0 \mathrm{mg}$ of ethacridine lactate monohydrate, $2.75 \mathrm{mg}$ of methithioninium chloride, $2.0 \mathrm{mg}$ of acriflavine chloride. "API MelaFix" (API Aquarium Pharmaceuticals, USA) was used to activate wound healing. The active substance is Melaleuca alternifolia extract, which has antiseptic properties and promotes healing of wounds and damaged parts of fish bodies. The drugs were used in the form of a long bath. Mean values (x) and standard deviation (SD) were calculated to provide data. Statistical processing of absolute values was performed according to generally accepted methods, the difference between the average quantitative indices was assessed using the non-parametric Mann-Whitney U-test. The difference at $\mathrm{P}<0.05$ was considered statistically significant.

\section{Results}

In all the studied cases, the disease in angelfish occurred suddenly, and from the anamnesis data it was established that the release of new fish in aquariums was not carried out during the two months before the outbreaks of the disease. Clinical signs were recorded in $20-30 \%$ of the total 
number of individuals of $P$. scalare, other fish species ( $P$. tetrazona, B. melanopterus, T. leeri, T. chuna) which were kept with them in the same aquarium showed no signs of damage. In $80 \%$ of cases, the disease was registered in aquariums with a high density of fish stock, which caused a high level of organic water pollution. Also, in $50 \%$ of cases, the water temperature in the aquarium was $20-23^{\circ} \mathrm{C}$, which did not meet the standards for keeping $P$. scalare.

Decreased appetite, decreased motor activity during feeding, and total feed intake were initially reported in diseased angelfish. At the beginning of the disease in some areas of the skin, fins and gills of fish, in some
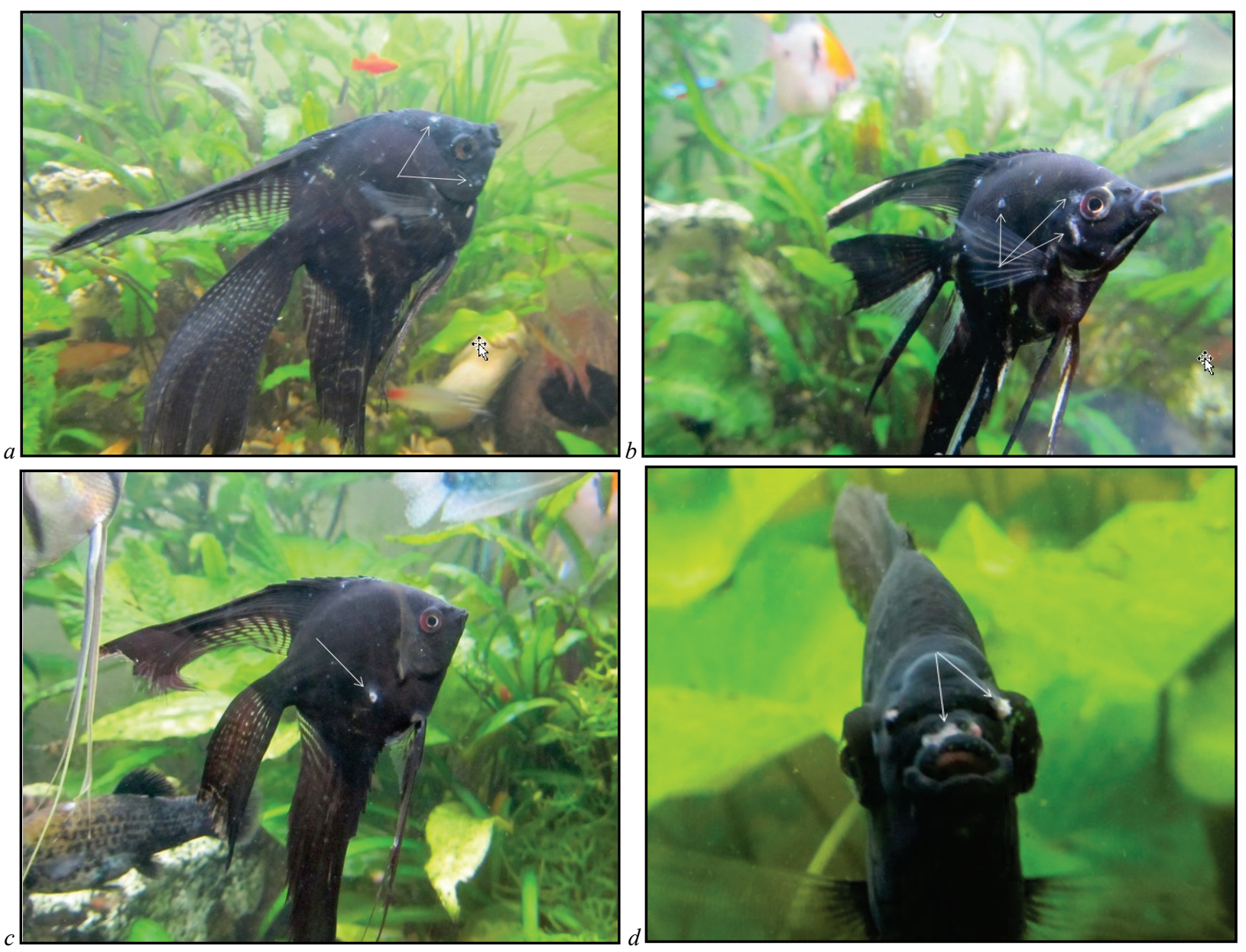

Fig. 2. Lesions of the skin of $P$. scalare with infections of S. parasitica (first - the third day of the disease): $a$-small white spots on the gill cover, $b$ - white spots of different shapes and sizes, located on different parts of the body, $c$-round-shaped ulcer on the lateral surface, $d$ - white spongy formations over the oral cavity
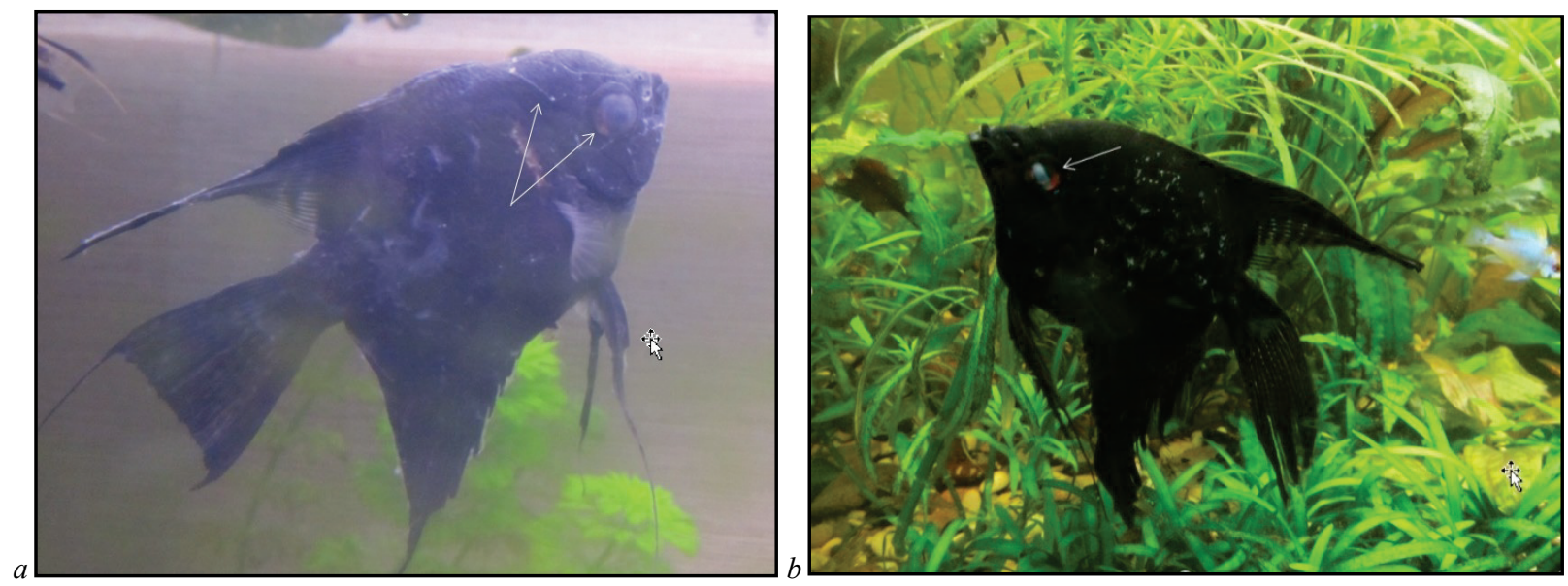

Fig. 3. Lesions of the skin of $P$. scalare with infections of $S$. parasitica (fourth - the sixth day of the disease): $a$-white thin threads on the surface of the scales, $b$-clouding of the cornea 
During the first seven days of the disease, $40 \%$ of infected individuals died. The dead fish were dissected and mycological studies were performed. When cultivating the affected fragments of fins and skin on Chapek's agar, on the fourth day, there grew large fluffy white, grey, greenish or yellowish colonies consisting of unseptated hyphae with rounded zoosporangia at their ends (Fig. 4).

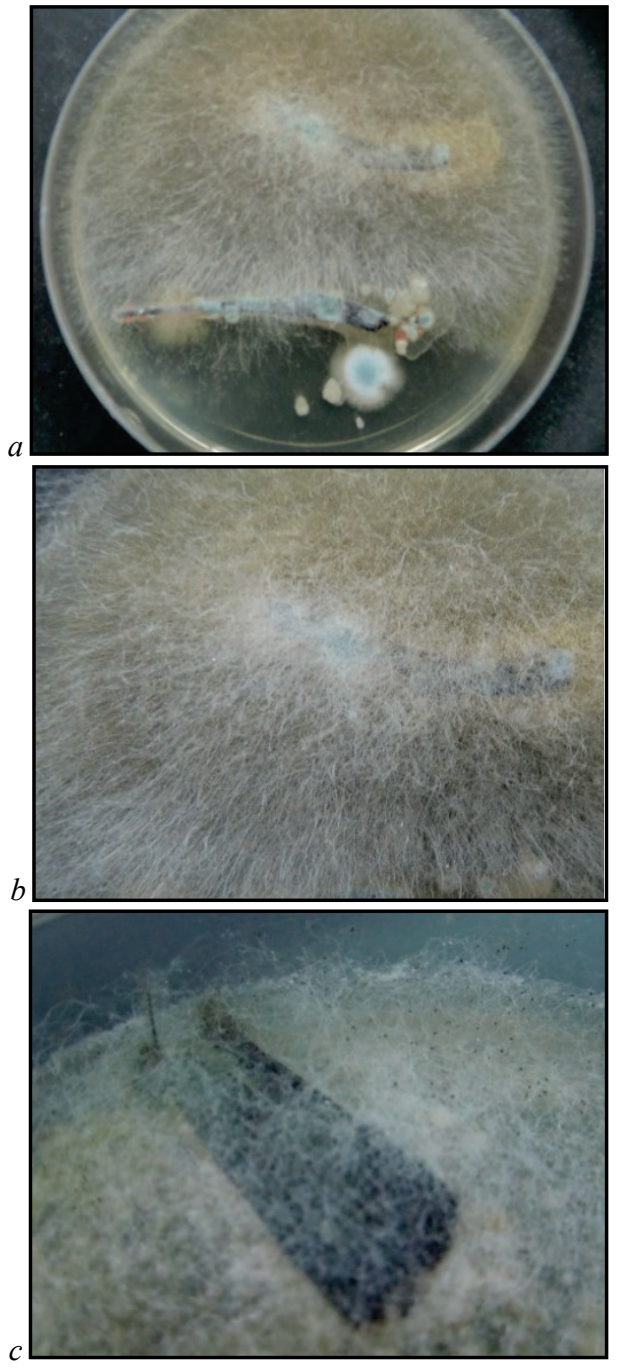

Fig. 4. Colonies of S. parasitica on Chapek's agar, the fourth day of fish fin fragments' cultivation with signs of damage: $a$-inoculation of pectoral fins' fragments, $b$-inoculation of pectoral fin's fragments, $c$ - inoculation of caudal fin's fragments

Microscopic examinations revealed extensive diffuse mycelium (Fig. 5). Hyphae were branched, hard. Hyphae were solitary, cylindrical or irregularly rounded, thermal, emitted zoospores. The study of morphological and cultural properties of colonies grown on agar, as well as microscopic studies permitted us to establish the affiliation of the pathogen to the Saprolegnia genus, a species of $S$. parasitica. The results of mycological studies of feeds used for feeding aquarium fish are shown in Table 1. Among dry feeds, the most affected by fungi were dry D. pulex (Fig. 6): in all samples $(100 \%)$ a significant level of micromycete contamination was found $-24.0 \pm 1.3 \mathrm{CFU} / \mathrm{g}$. Microscopic fungi were represented by the genera Aspergillus, Penicilium, Fusarium, Mucor.

In samples of dry granulated feeds, micromycetes were found in two samples $(14.2 \%)$ in insignificant concentrations: in flakes $-6.0 \pm$ $1.1 \mathrm{CFU} / \mathrm{g}$, and in chips $-2.2 \pm 0.8 \mathrm{CFU} / \mathrm{g}$. Micromycetes were represented by the Penicilium genus. The most common species of live food were larvae of C. plumosus. Their advantages are a significant amount of complete protein, which is easily digested by fish. In addition, live food moves, which allows the fish to maintain their natural reflexes. Live feeds spoil water much less than dry feeds, but they can be a factor in the transmission of various infections and invasions and contain toxins. The larvae of
C. plumosus have a bright red colour, are up to $25 \mathrm{~mm}$ in size, are the most nutritious species of live food, the protein content is about $60 \%$. We studied samples of C. plumosus larvae - the food was examined fresh (Fig. 6). It was found that all the studied samples $(100 \%)$ were significantly contaminated with microscopic fungi, after four days of cultivation on agar was $31.0 \pm 1.4 \mathrm{CFU} / \mathrm{g}$. Micromycetes were represented by the genera Aspergillus, Penicilium, Fusarium, Mucor, Rhizopus.

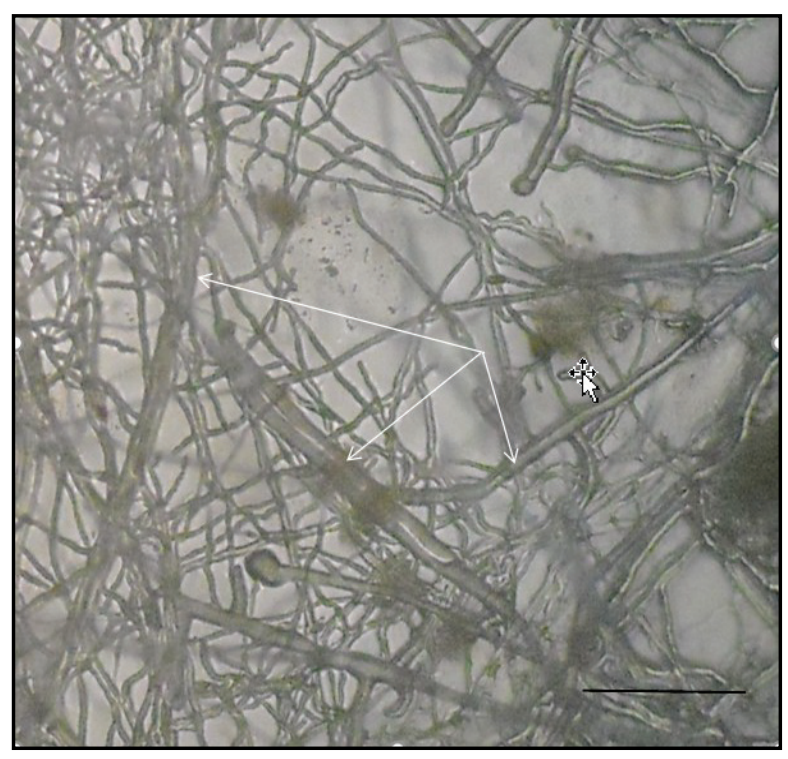

Fig. 5. Diffuse mycelium of $S$. parasitica (the fourth day of cultivation on Chapek's agar): $b a r=10 \mu \mathrm{m}$

\section{Table 1}

The content of micromycetes in feed for aquarium fish with outbreaks of saprolegniosis in $P$. scalare $(\mathrm{x} \pm \mathrm{SD}, \mathrm{n}=6)$

\begin{tabular}{|c|c|c|}
\hline Studied feeds & $\begin{array}{c}\text { The content of } \\
\text { micromycetes, } \\
\text { CFU/g }\end{array}$ & $\begin{array}{l}\text { Micromycetes, } \\
\text { genus }\end{array}$ \\
\hline $\begin{array}{l}\text { "TetraPro Energy" (Tetra, Germany) } \\
\text { (dry granulated feed) }\end{array}$ & $2.2 \pm 0.8$ & Penicilium \\
\hline $\begin{array}{l}\text { "TetraMin"(Tetra, Germany) } \\
\text { (dry granulated feed) }\end{array}$ & $6.0 \pm 1.1$ & Penicilium \\
\hline Daphnia pulex (dried feed) & $24.0 \pm 1.3$ & $\begin{array}{l}\text { Aspergillus, Penicilium, } \\
\text { Fusarium, Mucor }\end{array}$ \\
\hline $\begin{array}{l}\text { Larvae of Chironomus plumosus } \\
\text { (fresh feed) }\end{array}$ & $31.0 \pm 1.4$ & $\begin{array}{l}\text { Aspergillus, Penicilium, } \\
\text { Fusarium, Mucor, Rhizopus }\end{array}$ \\
\hline Artemia salina (frozen feed) & $0.0 \pm 0.0$ & - \\
\hline
\end{tabular}

A. salina is a small crustacean that lives in saltwater, adults reach a size of $8-10 \mathrm{~mm}$. The advantage of Artemia is the possibility of cultivation in artificial conditions, so it is the safest live food for fish. Mycological studies of samples of frozen Artemia did not reveal microscopic fungi.

Thus, the presence of epiphytic micromycetes was found in $44.4 \%$ of the total number of studied feed samples. Among the studied feed samples, the larvae of $C$. plumosus and dried D. pulex are the most affected by fungi. Micromycetes in the studied feed samples were represented by the genera Aspergillus, Penicilium, Fusarium, Mucor, Rhizopus. High contamination of fish feed with micromycetes leads to their entry into the aquatic environment and displacement of autochthonal microflora, which provides self-purification of water. $8.3 \%$ and $5.5 \%$ of the studied feed samples were toxic and slightly toxic. The vast majority of samples of dry D. pulex had toxic properties. The studies performed confirm the necessity of carrying out monitoring mycological studies of forages for aquarium fishes.

Due to the existence of fish in a closed hydroecosystem, it is not advisable to consider any infectious disease, including saprolegniosis, as a problem of diseased fish only. Water is the natural habitat of aquatic organisms and most infectious diseases develop in the case of violation of the ecobalance of a closed hydraulic system, resulting in the activation of pathogenic microbiota. Therefore, it is not enough to treat only diseased individuals without taking into account changes in the hydrochemical regime 
and imbalance of the aquarium ecosystem. To determine changes in the hydrochemical regime, a study of aquarium water during an outbreak of saprolegniosis was performed, the results of the studies are presented in Table 2.
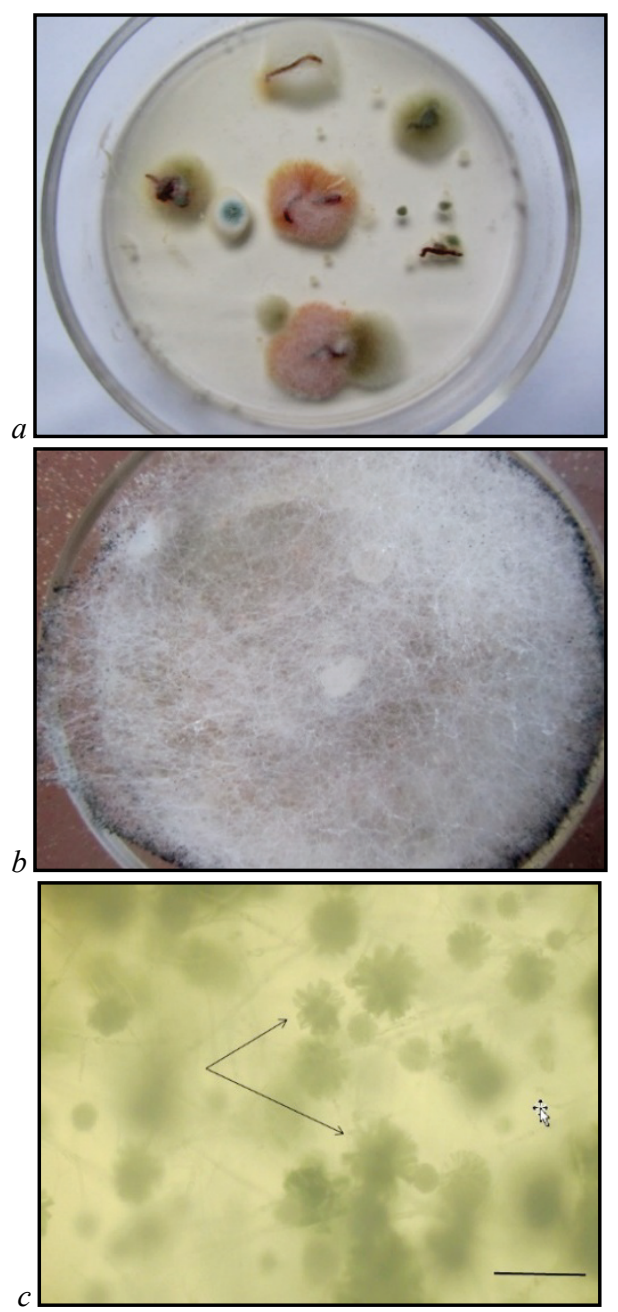

Fig. 6. Colonies of micromycetes on Chapek agar: $a$-inoculation of larvae of Chironomus plumosus (the fourth day of cultivation), $b$-inoculation of Daphnia pulex (the seventh day of cultivation), $c-$ spherical spore heads of Aspergillus spp. (the seventh day of cultivation): $\mathrm{bar}=10 \mu \mathrm{m}$

The chemical parameters of aquarium water during the outbreak of saprolegniosis were as follows: nitrate content $-16.4 \pm 1.1 \mathrm{mg} / \mathrm{L}$, phosphate $-5.6 \pm 1.1 \mathrm{mg} / \mathrm{L}, \mathrm{pH}-8.1 \pm 0.7$. The data obtained indicate an alkaline reaction of water, the level of nitrates was within normal limits, but the phosphate content was exceeded. Such indices may be due to the high density of fish in aquariums and excessive feeding of fish, when unconsumed feed residues decompose to form phosphates.

In the aquarium water samples taken during the saprolegniosis outbreak, the micromycete content was $18.0 \pm 1.2 \mathrm{CFU} / 100 \mathrm{~cm}^{3}$. The studied samples were dominated by representatives of the Aspergillus and Penicilium genera, species: A. flavus, $A$. niger and $P$. canescens. Representatives of the Saprolegnia genera also occurred, but much less frequently. On the tenth day after treatment, the content of nitrates was $16.0 \pm 0.8 \mathrm{mg} / \mathrm{L}$, nitrites $-0.15 \pm 0.1 \mathrm{mg} / \mathrm{L}$, phosphates $-4.2 \pm 1.2 \mathrm{mg} / \mathrm{L}, \mathrm{pH}-7.8 \pm 0.5$. The content of micromycetes decreased by $14.0 \%$ and was $15.6 \pm$ $1.4 \mathrm{CFU} / 100 \mathrm{~cm}^{3}$.

For the treatment of fish we used acriflavine chloride. For this it was introduced into the aquarium water on the first day at the rate of $6 \mathrm{mg}$ per $100 \mathrm{~L}$, on the second day $-3 \mathrm{mg}$ per $100 \mathrm{~L}$. In the first two days after treatment, the fish were not fed. On the 3-6th days of treatment, the drug was not introduced into the water, the fish were fed twice a day with dry granulated feed. On the seventh day, acriflavine chloride was added to the water at the rate of $6 \mathrm{mg}$ per $100 \mathrm{~L}$ of aquarium water (fish were not fed). To enhance wound healing, M. alternifolia extract was used, which was added to water at the rate of $5 \mathrm{~mL}$ per $40 \mathrm{~L}$ of aquarium water daily for seven days. On the eighth day after the start of treatment, $30 \%$ of the water in the aquarium was replaced. After replacing the water to completely remove the active substance residues, the water was filtered through activated carbon for two days, after which it was removed.

\section{Table 2}

Indices of aquarium water in outbreaks of saprolegniosis in P. scalare $(\mathrm{x} \pm \mathrm{SD}, \mathrm{n}=5)$

\begin{tabular}{|c|c|c|c|}
\hline $\begin{array}{c}\text { Indices } \\
\text { of aquarium } \\
\text { water } \\
\end{array}$ & $\begin{array}{l}\text { Before } \\
\text { treatment }\end{array}$ & $\begin{array}{l}\text { On the 10-th day } \\
\text { after the beginning } \\
\text { of treatment }\end{array}$ & $\begin{array}{c}30 \text { days after } \\
\text { the performed } \\
\text { treatment }\end{array}$ \\
\hline $\mathrm{pH}$ & $8.1 \pm 0.7$ & $7.8 \pm 0.5$ & $7.1 \pm 0.5^{*}$ \\
\hline Nitrates, mg/L & $16.4 \pm 1.1$ & $16.0 \pm 0.8$ & $15.5 \pm 1.2$ \\
\hline Phosphates, mg/L & $5.6 \pm 1.1$ & $4.2 \pm 1.2$ & $1.5 \pm 0.5^{*}$ \\
\hline $\begin{array}{l}\text { Content of micromy- } \\
\text { cetes, } C F U / 100 \mathrm{~cm}^{3}\end{array}$ & $18.0 \pm 1.2$ & $15.6 \pm 1.4^{*}$ & $6.2 \pm 0.4^{*}$ \\
\hline Micromycetes, genus & $\begin{array}{l}\text { Aspergillus, } \\
\text { Penicilium, } \\
\text { Saprolegnia }\end{array}$ & $\begin{array}{l}\text { Aspergillus, } \\
\text { Penicilium, } \\
\text { Saprolegnia }\end{array}$ & $\begin{array}{l}\text { Aspergillus, } \\
\text { Penicilium, } \\
\text { Saprolegnia }\end{array}$ \\
\hline
\end{tabular}

Note: * $-\mathrm{P}<0.05$ compared to the indices before treatment.

During the treatment, the aquarium water was heated and the temperature was $25-27^{\circ} \mathrm{C}$. Feed contaminated with micromycetes with toxic and slightly toxic characteristics was excluded from the diet of fish, and fish were only fed with dry granulated feed. We reduced the fish-holding density in the aquariums. During the period of treatment and recovery, no new fish were released, as they are primarily the most susceptible to the microflora present in the water. Because our aquarium water had an alkaline reaction with a high phosphate content and a high micromycete content, $20 \%$ of the aquarium volume was changed every two days during two week treatment. For this purpose, filtered and remineralized water was used and active water aeration was provided. As a result of the treatment, gradual healing of skin lesions and recovery of $65 \%$ of fish with signs of lesions of the outer coverings were registered. 30 days after treatment, the chemical parameters of aquarium water were as follows: nitrate content $-15.5 \pm 1.2 \mathrm{mg} / \mathrm{L}$, phosphate $-1.5 \pm 0.5 \mathrm{mg} / \mathrm{L}, \mathrm{pH}-7.1 \pm 0.5$. The content of micromycetes was $6.2 \pm 0.4 \mathrm{CFU} / 100 \mathrm{~cm}^{3}$. These indices answered the normative values for a balanced hydraulic system. During the next two months, no new cases of the disease were detected among the angelfish. Thus, the measures taken permitted us to eliminate the outbreak of saprolegniosis in aquarium fish and to restore the biological balance in a closed eco-hydraulic system of the aquarium.

To prevent saprolegniosis in angelfish optimal conditions should be created for their keeping, to monitor the indices of the hydrochemical regime, to ensure full feeding with quality feed. When catching and transplanting and other manipulations with fish, care should be taken to avoid injuring them. It is necessary to periodically maintain the proper sanitary condition of the aquarium: remove unconsumed food, dead parts of plants, carcasses, to prevent overpopulation of the aquarium and significant overgrowth of aquatic vegetation.

\section{Discussion}

The biocoenotic role of fungi is due to a set of abiotic factors characteristic of a particular water body. It is the specifics of hydrology and hydrochemistry of these hydroecosystems that determine the uniqueness of the relationship between representatives of the microbiota and other organisms (Rudenko et al., 2011). Micromycetes are widespread in the environment, they are an integral part of it. Recently, however, micromycetes have often been the cause of infectious diseases. A group of researchers presented data on the presence of micromycetes in both surface water supply sources and tap water. A wide range of microscopic fungi was identified, among which the representatives of the genera Penicillium, Aspergillus, Trichoderma dominated (Novak et al., 2016; Dogget, 2000). The Saprolegnia genus (Saprolegniales: Oomycota) includes more than 20 species that are widespread throughout the world. This genus includes pathogens that cause a significant reduction in wildlife and aquaculture populations. 
In particular, the genus Saprolegnia includes pathogens that affect the embryonic and adult stages of fish. Therefore, there is a need for a better understanding of the biology of these microscopic fungi (Van den Berg et al., 2013). Cases of mass death of angelfish caviar occurred in a private farm for growing ornamental fish in Egypt due to damage by fungi of the Saprolegnia genus (Eissa et al., 2013).

Our studies have identified cases of disease in angelfish in aquariums caused by $S$. parasitica. Outbreaks of saprolegniosis among angelfish have been linked to a number of adverse factors during fish keeping. In particular, high fish-holding density, significant levels of organic water pollution, low water temperature for long durations. The obtained data of chemical parameters of water indicate an alkaline reaction and high phosphate content. Such indices may be the result of overfeeding fish and a significant fish-holding density. The content of micromycetes in the studied samples of aquarium water was $18.0 \pm 1.2 \mathrm{CFU} / 100 \mathrm{~cm}^{3}$. The following species dominated: A. flavus, $A$. niger and $P$. canescens. Representatives of the Saprolegnia genus were also found, but much less frequently. Our data are consistent with studies by Davidov \& Temnihanov (2004), who report that the occurrence and exacerbation of mycoses among fish is facilitated by poor feeding of fish and excessive water pollution by organic matter.

Saprolegnia spp. cause significant damage to aquaculture, so the search for effective and environmentally friendly means to control these oomycetes is relevant (Nardoni et al., 2019). Malachite green has previously been widely used to treat saprolegniosis, but is not currently used due to possible genotoxicity, carcinogenicity, and residual toxicity (Van West et al., 2010). Currently, there is an active search for chemicals that would provide adequate protection against the disease (Yao et al., 2010). The only compounds approved by the US Food and Drug Administration to control the fungus are $37 \%$ formalin and $35 \%$ hydrogen peroxide, but their efficacy is lower than that of malachite green (Straus et al., 2016). The efficacy of boric acid in preventing infection of fish with saprolegniosis (Oreochromis niloticus) (Ali et al., 2019) has been established. Ethanol extracts of Punica granatum and Thymus vulgaris have shown potential efficacy in inhibiting the growth of $S$. diclina mycelium at a concentration of $0.5 \mathrm{mg} / \mathrm{mL}$ (Mostafa et al., 2020).

In our study, for the treatment of fish, acriflavine chloride and M. alternifolia extract were used in the form of a long bath. During the treatment period, the water was heated to a temperature of $25-27^{\circ} \mathrm{C}$. As our study showed that aquarium water had an alkaline reaction with a high phosphate content, $20 \%$ of the aquarium volume was replaced every other day for two weeks by using filtered and remineralized water and aerating it. From the diet of fish we excluded feed contaminated with epiphytic micromycetes, with toxic and slightly toxic characteristics. As a result of the treatment, recovery of $65 \%$ of fish with signs of damage to the outer coverings was registered. Thus, the measures permitted us to eliminate the outbreak of saprolegniosis in aquarium fish and to restore the biological balance in the closed eco-hydraulic system of the aquarium.

\section{Conclusion}

It is established that saprolegniosis in angelfish arose against the background of adverse changes in physical, chemical composition and microbiocenosis of aquarium water. During outbreaks of saprolegniosis, aquarium water had an alkaline reaction, $\mathrm{pH}-8.1 \pm 0.7$, and elevated phosphate content $-5.6 \pm 1.1 \mathrm{mg} / \mathrm{L}$. The content of micromycetes was $18.0 \pm 1.2$ $\mathrm{CFU} / 100 \mathrm{~cm}^{3}$, with representatives of the Aspergillus and Penicillium genera dominating. Mycological studies of feed for aquarium fish revealed contamination with epiphytic micromycetes in $44.4 \%$ of the studied samples, which were represented by the Aspergillus, Penicilium, Fusarium, Mucor, Rhizopus genera. Toxic properties were found in $8.3 \%$ of the studied samples, slightly toxic - in 5.5\%. Among the studied feed samples, the most affected by micromycetes were larvae of $C$. plumosus $(31.0 \pm 1.4 \mathrm{CFU} / \mathrm{g})$ and dry D. pulex $(24.0 \pm 1.3 \mathrm{CFU} / \mathrm{g})$. High contamination of these feeds with microscopic fungi leads to their entry into the aquatic environment and is a risk factor for cultured fish. It was found that the use of acriflavine chloride (6 mg per $100 \mathrm{~L}$ of aquarium water) and extract of M. alternifolia ( $5 \mathrm{~mL}$ per $40 \mathrm{~L}$ of aquarium water) in the form of a long bath provides recovery of $65 \%$ of diseased angelfish. It is proved that effective measures are raising the water temperature to $25-27^{\circ} \mathrm{C}$, compliance with the normative fish-holding density in aquariums, periodic water replacement and aeration. It is also necessary to control the quality of feed for aquarium fish, it is impossible to allow feeding with feed contaminated with epiphytic micromycetes. One month after treatment, the content of nitrates in aquarium water was $15.5 \pm 1.2 \mathrm{mg} / \mathrm{L}$, phosphates $1.5 \pm 0.5 \mathrm{mg} / \mathrm{L}, \mathrm{pH}-7.1 \pm 0.5$, the content of micromycetes $-6.2 \pm$ $0.4 \mathrm{CFU} / 100 \mathrm{~cm}^{3}$. These indices answer the normative values for a balanced hydraulic system.

\section{References}

Ali, S., Gamil, A., Skaar, I., Evensen, Q., \& Charo-Karisa, H. (2019). Efficacy and safety of boric acid as a preventive treatment against Saprolegnia infection in Nile tilapia (Oreochromis niloticus). Scientific Reports, 9(1), 18013.

Carrias, A., Ran C., Terhune, J. S., \& Liles, M. R. (2012). Infectious disease in aquaculture. Woodhead Publishing, Auburn University.

Choi, Y. J., Lee, S. H., Nguyen, T., Nam, B., \& Lee, H. B. (2019). Characterization of Achlya americana and A. bisexualis (Saprolegniales, Oomycota) isolated from freshwater environments in Korea. Microbiology, 47(2), 135-142.

Davydov, O. M., \& Temnikhanov, Y. D. (2004). Osnovy veterynarno-sanitarnoho kontroliu v rybnytstvi [Fundamentals of veterinary and sanitary control in fish farming]. Inkos, Kyiv (in Ukrainian).

Dogget, M. S. (2000). Characterization of fungal biofilm within a municipal water distribution system. Applied and Environmental Microbiology, 66(3), 1249 1251.

Eissa, A. E., Abdelsalam, M., Tharwat, N., \& Zaki, M. (2013). Detection of Saprolegnia parasitica in eggs of angelfish Pterophyllum scalare (CuvierValenciennes) with a history of decreased hatchability. International Journal of Veterinary Science and Medicine, 1(1), 7-14.

Gallani, S. U., Sebastião, F. A., Valladão, G. M. R., Boaratti, A. Z., \& Pilarski, F. (2016). Pathogenesis of mixed infection by Spironucleus sp. and Citrobacter freundii in freshwater angelfish Pterophyllum scalare. Microbial Pathogenesis, 100, 119-123.

Gaulin, E., Bottin, A., \& Dumas, B. (2010). Sterol biosynthesis in oomycete pathogens. Plant Signaling and Behavior, 5(3), 258-260.

Greeff-Laubscher, M., Christison, K., \& Smit, N. (2019). First record of the water mold Achlya bisexualis (Saprolegniaceae) isolated from ornamental fish in South Africa. Journal of Aquatic Animal Health, 31(4), 354-363.

Kar, D. (2016). Epizootic ulcerative fish disease syndrome. Academic Press, Silchar.

Ke, X., Wang, J., Gu, Z., Li, M., \& Gong, X. (2009). Morphological and molecular phylogenetic analysis of two Saprolegnia sp. (Oomycetes) isolated from silver crucian carp and zebra fish. Mycological Research, 113(5), 637-644.

Lange, M. D., Farmer, B. D., \& Abernathy, J. (2020). Vertebrate mucus stimulates biofilm development and upregulates iron acquisition genes in Flavobacterium columnare. Journal of Fish Diseases, 43(1), 101-110.

Masigol, H., Khodaparast, S., Mostowfizadeh-Ghalamfarsa, R., Rojas-Jimenez, K., Woodhouse, J., Neubauer, D., \& Grossart, H. (2020). Taxonomical and functional diversity of Saprolegniales in Anzali lagoon, Iran. Aquatic Ecology, 54, 323-336.

Mostafa, A., Al-Askar, A., \& Yassin, M. (2020). Anti-Saprolegnia potency of some plant extracts against Saprolegnia diclina, the causative agent of saprolengiasis. Saudi Journal of Biological Sciences, 27(6), 1482-1487.

Nardoni, S., Najar, B., Fronte, B., Pistelli, L., \& Mancianti, F. (2019). In vitro activity of essential oils against Saprolegnia parasitica. Molecules, 24(7), 1270.

Novak, B. M., Zalar, P., Ženko, B., Džeroski, S., \& GundeCimerman, N. (2016). Yeasts and yeast-like fungi in tap water and groundwater, and their transmission to household appliances. Fungal Ecology, 20, 30-39.

Obrazhej, A. F., Pogrebnjak, L. I., \& Korzunenko, O. F. (1998). Metodichni vkazivki po sanitarno-mikologichnij ocinci ta polipshennju jakosti kormiv [Methodological instructions on sanitary-mycological assessment and improvement of feed quality]. Vydavnytstvo Instytutu Vetmedytsyny ta Tsentralnoi Derzhavnoi Laboratorii Vetmedytsyny Ministerstva APK Ukrainy, Kyiv (in Ukrainian).

Pulkkinen, K., Pekkala, N., Ashrafi, R., Hämäläinen, D. M., Nkembeng, A. N., Lipponen, A., Hiltunen, T., Valkonen, J., \& Taskinen, J. (2018). Effect of resource availability on evolution of virulence and competition in an environmentally transmitted pathogen. FEMS Microbiology Ecology, 94(5), fiy060.

Rudenko, A. V., Savluk, O. S., Saprykina, M. N., \& Jasremskaja, A. V. (2011). Mikromicety v vode r. Dnepr [Micromycetes in the water of the Dnipro River]. Chemistry and Technology of Water, 33(5), 543-550 (in Russian).

Satton, D., Fotergill, A., \& Rinal'di, M. (2001). Opredelitel' patogennyh i uslovno patogennyh gribov [Keys to pathogenic and opportunistic fungi]. Mir, Moscow (in Russian).

Straus, D. L., Farmer, B. D., Ledbetter, C. K., Beck, B. H., Williams, R. S., Clark, M. L., \& Freeze, T. M. (2016). Use of copper sulfate to control egg saprolegniasis at a commercial sunshine bass hatchery. North American Journal of Aquaculture, 78, 243-250. 
Sundberg, L. R., \& Karvonen, A. (2018). Minor environmental concentrations of antibiotics can modify bacterial virulence in co-infection with a non-targeted parasite. Biology Letters, 14(12), 20180663.

Van den Berg, A. H., McLaggan, D., Diéguez-Uribeondo, J., \& Van West, P. (2013). The impact of the water moulds Saprolegnia diclina and Saprolegnia parasitica on natural ecosystems and the aquaculture industry. Fungal Biology Reviews, 27(2), 33-42.

Van West, P., de Bruijn, I., Minor, K. L., Phillips, A. J., Robertson, E. J., Wawra, S., Bain, J., Anderson, V. L., \& Secombes, C. J. (2010). The putative R $\times$ LR effector protein $\mathrm{SpHtp} 1$ from the fish pathogenic oomycete Saprolegnia parasitica is translocated into fish cells. FEMS Microbiology Letters, 310(2), 127-137.
Watkinson, S., Boddy, L., \& Money, N. (2016). The fungi (Third Edition). Academic Press, Oxford.

Wuensch, A., Trusch, F., Iberahim, N., \& Van West, P. (2018). Galleria melonella as an experimental in vivo host model for the fish-pathogenic oomycete Saprolegnia parasitica. Fungal Biology, 122, 182-189.

Yao, J. Y., Shen, J. Y., Li, X. L., Xu, Y., Hao, G. J., Pan, X. Y., Wnag, G. X., \& Yin, W. L. (2010). Effect of sanguinarine from the leaves of Macleaya cordata against Ichthyophthirius multifiliis in grass carp (Ctenopharyngodon idella). Parasitology Research, 107, 1035-1042. 